\title{
Kemampuan Selulosa Daun Mahkota Nanas (Ananas comosus) Sebagai Bioadsorben Logam Tembaga $(\mathrm{Cu})$
}

Ability of Cellulose by Pineapple Crown Leaf (Ananas comosus) Cellulose as Bio-adsorbent of Heavy Metal Copper $(\mathrm{Cu})$

\author{
Desinyata Yosefina Keon ${ }^{1 *}$, Indah Murwani Yulianti ${ }^{1}$, Wibowo Nugroho Jati ${ }^{1}$ \\ ${ }^{1}$ Fakultas Teknobiologi Universitas Atma Jaya Yogyakarta, Yogyakarta \\ Email: deshykeon@gmail.com *Penulis untuk korespondensi
}

\begin{abstract}
Heavy metals waste from industrial processes can cause pollutions in the environment. One way that can be used to overcome waste problem in environment is by bio-absorbent technology. In this study, the bio-absorbent used was cellulose from pineapple crown leaf. The aim of this study was (1) to identify the ability of cellulose by pineapple crown leaf in lowering copper $(\mathrm{Cu})$ levels, (2) to identify the cellulose level to decrease copper ( $\mathrm{Cu}$ ) content, (3) to identify the influence of cellulose and time variance on $\mathrm{Cu}$ level, Total Dissolve Solid (TDS), Total Suspended Solid (TSS) and pH. Experimental design used in this study was a completely randomized factorial design with two treatments (cellulose and time variance) and three repetitions. The quantitative result of this study was presented in the form of table and graphs. Cu content, TDS, TSS, and pH was analyzed using ANOVA with SPSS. Result of this study showed that with addition of cellulose and time variance there was a decrease of copper levels by $72.87 \%$ in one hour with 1.5 $\mathrm{g}$ cellulose as well as increase in TDS, TSS levels from 0 to 3 hours and increase in pH. Based on the Regulation of the Minister of Environtment of Republic of Indonesia No. 5, 2014 copper and pH levels in this study have not meet the quality standard while TDS and TSS levels are below the waste quality standard.
\end{abstract}

Keywords: Waste, Copper (Cu), Bioadsorbent, Pineapple leaf crown, Cellulose.

\section{Abstrak}

Air limbah yang mengandung logam berat dari proses industri dapat menyebabkan pencemaran lingkungan. Salah satu cara yang dapat digunakan untuk mengatasi masalah limbah di lingkungan adalah dengan teknologi bioadsorbsi. Bioadsorben yang digunakan dalam penelitian ini adalah selulosa daun mahkota nanas. Tujuan dari penelitian ini adalah (1) mengetahui kemampuan selulosa daun mahkota nanas dalam menurunkan kadar logam berat tembaga $(\mathrm{Cu})$, (2) mengetahui kadar selulosa daun mahkota nanas dalam menurunkan logam berat $\mathrm{Cu}$, (3) mengetahui pengaruh penambahan selulosa dan varisi waktu terhadap kadar $\mathrm{Cu}$, Total Dissolved Solids (TDS), Total Suspended Solid (TSS) dan pH. Rancangan percobaan yang digunakan dalam penelitian ini adalah Rancangan Acak Lengkap (RAL) Faktorial, yakni dengan dua perlakuan (variasi selulosa dan waktu) dan tiga kali pengulangan. Data hasil penelitian kuantitatif ini akan disajikan dalam bentuk tabel dan grafik. Kadar Cu, TDS, TSS dan nilai pH akan dianalisis menggunakan SPSS dengan uji ANAVA. Hasil penelitian menunjukkan bahwa dengan penambahan selulosa dan variasi waktu terjadi penurunan kadar Cu sebesar 72,87\% pada waktu 1 jam dengan selulosa 1,5 gr dan kenaikan kadar TDS dan TSS dari waktu 0 sampai 3 jam serta kenaikan nilai pH. Berdasarkan Peraturan Menteri Lingkungan Hidup Republik Indonesia No 5 Tahun 2014 kadar Cu dan pH dalam penelitian ini belum berada di bawah baku mutu sedangkan kadar TDS dan TSS sudah berada di bawah baku mutu limbah.

Kata Kunci: Limbah, Logam Berat Tembaga (Cu), Bioadsorben, Daun Mahkota Nanas, Selulosa 


\section{Pendahuluan}

Lingkungan yang tercemar seringkali menimbulkan dampak yang buruk bagi makhluk hidup yang ada di sekitarnya seperti, manusia, hewan dan tumbuhan. Logam berat merupakan salah satu penyebab lingkungan tercemar. Tembaga $(\mathrm{Cu})$ merupakan salah satu logam berat selain timbal $(\mathrm{Pb})$, merkuri $(\mathrm{Hg})$, Chrome $(\mathrm{Cr})$, dan seng $(\mathrm{Zn})$ yang dapat mencemari lingkungan perairan. Di alam, logam Cu biasanya ditemukan dalam bentuk logam bebas, tetapi lebih banyak ditemukan dalam bentuk senyawa padat bentuk mineral. Unsur $\mathrm{Cu}$ bersumber dari peristiwa pengikisan (erosi) batuan mineral, debu- debu dan partikulat $\mathrm{Cu}$ dalam lapisan udara yang dibawa turun oleh air hujan (Widowati dan Wahyu, 2008).

Bioadsorbsi merupakan salah satu cara yang bisa digunakan untuk mengurangi dampak pencemaran lingkungan tersebut. Bioadsorben dengan menggunakan biomaterial yakni tumbuhan yang telah mati untuk proses penyerapan disebut bioadsorbsi (Lestari dkk., 2003). Bioadsorben yang digunakan dalam penelitian ini adalah daun mahkota nanas (Ananas comosus). Daun mahkota nanas digunakan karena memiliki kandungan serat yang tinggi.

Menurut Norman (1937) terdapat 62\%$79 \%$ selulosa dalam serat daun nanas, sedangkan dalam Hidayat (2008), menyebutkan bahwa serat daun nanas mengandung 69,5\%-71,5\% selulosa. Menurut Kirby (1963), secara kimiawi, semua serat yang berasal dari tumbuhan, unsur utama yang ada dalam serat adalah selulosa, walaupun terdapat juga unsur lain seperti hemiselulosa, pektin, lignin dan zat- zat lainnya. Kandungan selulosa yang tinggi dalam daun mahkota nanas ini diharapkan dapat dijadikan alternatif baru sebagai bioadsorben logam berat tembaga $(\mathrm{Cu})$ dalam pengelolaan limbah cair yang lebih ekonomis dan ramah lingkungan.

\section{Metode Penelitian}

\section{Preparasi Daun Mahkota Nanas (Adinugraha dkk., 2005 dengan modifikasi)}

Daun mahkota nanas yang digunakan dicuci, kemudian dikeringkan, dipotong ukuran $\pm 1 \mathrm{~cm}$ lalu di-oven pada suhu $105^{\circ} \mathrm{C}$ selama 3 jam kemudian di-blender dan selanjutnya diayak dengan ukuran 90 mesh.

Isolasi Selulosa Daun Mahkota Nanas (Adinugraha dkk., 2005 dengan modifikasi)

\section{Delignifikasi Daun Mahkota Nanas}

Tepung atau serbuk daun mahkota nanas ditimbang sebanyak 50 gr kemudian dipanaskan dengan $\mathrm{NaOH} 12 \%$ sebanyak 500 ml selama 3 jam dengan suhu $100^{\circ} \mathrm{C}$. Setelah 3,5 jam, larutan disaring lalu dengan menggunakan aquadest residu dicuci sampai $\mathrm{pH}$ netral kemudian dikeringkan dengan suhu ruang.

\section{Bleaching (Pemurnian)}

Delignifikasi serbuk atau tepung daun mahkota nanas kemudian dipanaskan dengan $\mathrm{NaOCl}$ selama 1 jam dengan suhu $60^{\circ} \mathrm{Cmenggunakan}$ hot plate. Kemudian larutan disaring lalu dikeringkan dengan oven pada suhu $100^{\circ} \mathrm{C}$ selama 2 jam dan residu dibilas dengan aquades sampai $\mathrm{pH}$ netral

\section{Karakterisasi Selulosa Hasil Ekstraksi Daun Mahkota Nanas Menggunakan Metode Gravimetri (Metode Chesson (1978) dalam Data (1981) yang dimodifikasi}

Erlenmeyer $250 \mathrm{ml}$ (x) ditimbang dan 1 gram sampel serbuk daun mahkota nanas dimasukkan, dan $200 \mathrm{ml}$ aquades ditambahkan. Selama 2 jam larutan dalam erlenmeyer dipanaskan sambil diaduk beberapa kali. Selanjutnya, kertas saring ditimbang (k) dan larutan disaring menggunakan kertas saring.Sisa penyaringan pada kertas saring dipanaskan menggunakan oven pada suhu $105^{\circ} \mathrm{C}$ hingga beratnya konstan (1). Setelah itu, $200 \mathrm{ml} \mathrm{H}_{2} \mathrm{SO}_{4}$ 0,5 M ditambahakan ke dalam erlenmeyer 250 $\mathrm{ml}$ yang telah diisi residu, dengan menggunakan kertas saring residu disaring lagi dan $25 \mathrm{ml}$ $\mathrm{H}_{2} \mathrm{SO}_{4} 72 \%$ ditambahkan kemudian dibiarkan selama 3 jam pada erlenmeyer $250 \mathrm{ml}$. Selanjutnya, selama 2 jam dipanaskan menggunakan waterbath pada suhu $100^{\circ} \mathrm{C}$ yang telah ditambahkan aquades $150 \mathrm{ml}$ ke dalam erlenmeyer. Kemudian ditambahkan aquades hingga volumenya $300 \mathrm{ml}$. Kertas saring ditimbang (j) dan residunya disaring menggunakan kertas saring. Selanjutnya, 
ditimbang berat konstan (i) dan Kadar selulosa dapat dihitung menggunakan rumus:

$$
\% \text { kadar selulosa }=\frac{(l-k)-(i-j)}{x} \times 100 \%
$$

Keterangan:

X: berat awal Erlenmeyer

1: berat konstan setelah dioven suhu $105^{\circ} \mathrm{C}$

$\mathrm{k}$ : berat kertas saring awal

i: berat kertas saring akhir

$\mathrm{j}$ : berat konstan akhir

Pembuatan Larutan Stok dan Sampel Limbah Logam Berat Tembaga (Cu)

Konsentrasi 100 ppm dibuat sebagai larutan stock $\mathrm{Cu}$. $1 \mathrm{~L}$ aquades yang dimasukkan ke dalam erlenmeyer digunakan untuk melarutkan $100 \mathrm{~g} \mathrm{Cu}$. Larutan dimasukkan ke dalam toples masing- masing $30 \mathrm{ml}$.

\section{Pengukuran pH}

$\mathrm{pH}$ diukur menggunakan $\mathrm{pH}$ meter.

\section{Pengukuran Turbiditas}

Setelah diukur kadar pH, selanjutnya dilakukan pengukuran kadar TDS. Kadar TDS diukur menggunakan turbidimeter.

\section{Bioadsorbsi logam $\mathrm{Cu}$}

Kadar logam berat $\mathrm{Cu}$ diukur menggunkan spektrofotometer PC multidirect merk lovibond.

\section{Pengukuran TSS}

Kertas saring whatman ukuran 0,043 mikron dikeringkan dalam oven pada suhu $80{ }^{\circ} \mathrm{C}$ selama 24 jam kemudian ditimbang untuk mengetahui berat awal, (a) kertas saring tersebut.
Kemudian sampel (V=30 $\mathrm{ml})$ disaring menggunakan kertas saring yang telah diketahui berat awalnya. Selanjutnya, kertas saring yang telah berisi sampel, dikeringkan dalam oven pada suhu $80{ }^{0} \mathrm{C}$ selama 24 jam. Kemudian ditimbang kembali untuk mengetahui berat akhir (b). Total suspended solid dihitung dengan rumus:

$$
\mathrm{TSS}=\frac{b-a}{V} \times 1000
$$

\section{Keterangan :}

a: berat awal

b: berat akhir

v: volume sampel

\section{Analisis Data}

Data hasil penelitian yang diperoleh akan dianalisis statistik menggunakan korelasi regresi dan untuk mengetahui ada tidaknya beda nyata antar perlakuan dilakukan uji ANAVA. Uji Duncan's Multiple Range Test (DMRT) dilakukan jika terdapat beda nyata dan uji dilakukan pada tingkat kepercayaan 95\% untuk melihat letak beda nyata. Perhitungan korelasi dan regresi pengaruh variabel bebas terhadap variabel terikat dapat dilihat pada persamaan berikut: $\mathrm{Y}=\mathrm{a}+\mathrm{bx}$.

\section{Hasil dan Pembahasan}

\section{Hasil Ekstraksi Selulosa Daun Mahkota Nanas}

Hasil pemurnian serbuk daun mahkota nanas dapat dilihat pada Gambar 1.

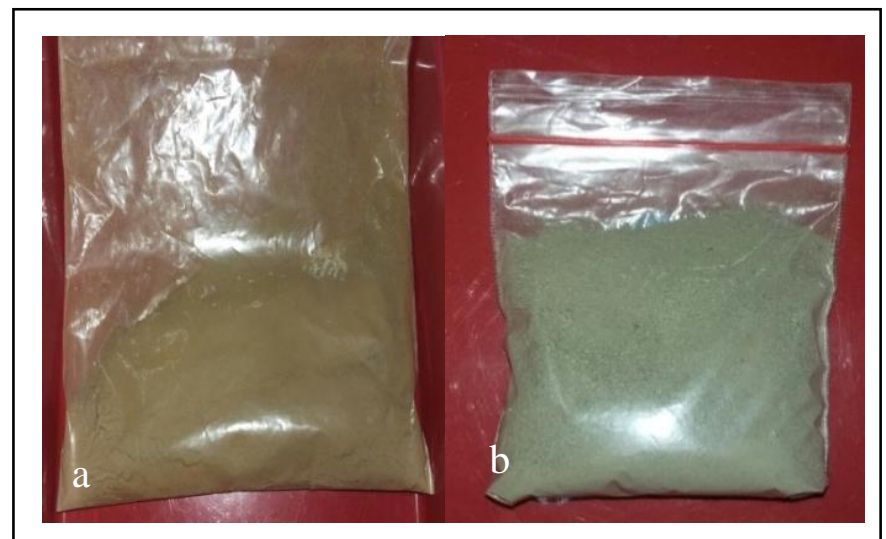

Gambar 1. a. Serbuk daun mahkota nanas sebelum diekstraksi b.Serbuk daun mahkota nanas setelah diekstraksi 
Perubahan warna yang terjadi pada serbuk selulosa daun mahkota nanas selain dikarenakan adanya proses pemutihan juga disebabkan adanya proses hidrolisis dan delignifikasi sehingga serbuk selulosa terpisah dari lignin dan memiliki kemurnian selulosa yang tinggi. Hal ini sesuai dengan pendapat Sumardjo (2009), yang menyatakan bahwa selulosa berupa zat padat amorf, berwarna putih, yang tidak larut dalam air dan pelarut organik umum.Indikasi larutnya lignin dapat diketahui dengan berkurangnya berat sampel dan adanya perubahan warna serbuk (Safrianti dkk., 2012).

\section{Bioadsorben Logam Berat Tembaga $(\mathrm{Cu})$}

Kemampuan daun mahkota nanas sebagai biosorben dalam penelitian ini dibuktikan dengan adanya penurunan kadar logam tembaga seperti pada Gambar 2.

Berdasarkan Gambar 2 dapat diketahui bahwa pada waktu 1 jam dengan penambahan selulosa 1,5 gram dapat mengadsorbsi $\operatorname{logam} \mathrm{Cu}$ paling tinggi dengan sisa kadar $\mathrm{Cu}$ sebesar 13,57 ppm dibandingkan dengan waktu 2 jam dan 3 jam yakni 14,47 ppm dan 14,53 ppm dan dengan menggunakan tingkat kepercayaan 95\% dari uji statistik menunjukkan adanya beda nyata. Titik optimum dicapai pada waktu aktivasi 24 jam dan pada waktu aktivasi 48 jam mengalami penurunan, hal ini disebabkan karena semakin lama waktu aktivasi, hemiselulosa yang terlarut semakin banyak, sehingga menurunkan banyaknya sisi aktif (Handayani, 2010). Berdasarkan Peraturan Menteri Lingkungan Hidup Republik Indonesia No 5 tahun 2014 tentang baku mutu air limbah kadar $\mathrm{Cu}$ yang dihasilkan dalam penelitian ini belum berada dibawah baku mutu.

\section{Penentuan Kadar Total Dissolved Solids (TDS)}

Penurunan dan kenaikan kadar TDS yang disebabkan karena perbedaan variasi penambahan selulosa dan waktu kontak yang berbeda dapat dilihat pada Gambar 3 .

Berdasarkan Gambar 3 dapat diketahui bahwa kadar TDS terendah terdapat pada perlakuan tanpa penambahan selulosa, sedangkan pada perlakuan dengan penambahan selulosa 0,5g, $1 \mathrm{~g}$ dan 1,5 g memiliki kadar TDS yang tinggi tapi dengan waktu kontak 3 jam mengalami penurunan tetapi tidak sebanding dengan kadar TDS pada perlakuan tanpa penambahan selulosa. Tingginya kadar TDS dengan waktu kontak 1 jam, 2 jam dan 3 jam dikarenakan adanya penambahan selulosa sebanyak 0,5 g, $1 \mathrm{~g}$ dan 1,5 g sehingga selulosa yang ditambahkan terbaca sebagai partikelpartikel serta zat- zat organik maupun anorganik yang ada di dalam larutan limbah tembaga. tingginya kadar TDS diakibatkan karena banyaknya terkandung senyawa-senyawa organik dan anorganik yang larut dalam air, mineral dan garam. Pada air laut nilai TDS yang tinggi dikarenakan banyak mengandung senyawa kimia, yang juga mengakibatkan tingginya nilai salinitas dan daya hantar listrik (Effendi, 2003). Berdasarkan hasil uji statistik dengan tingkat kepercayaan $95 \%$ terdapat beda nyata dan menurut Peraturan Menteri Lingkungan Hidup Republik Indonesia Nomor 5 Tahun 2014 Tentang Baku Mutu Air Limbah sudah memenuhi baku mutu air limbah.

\section{Penentuan Kadar Total Suspended Solid (TSS)}

Hasil kadar TSS yang diperoleh dari penelitian ini dapat dilihat pada Gambar 4.

Berdasarkan Gambar 4. dapat diketahui bahwa terjadi kenaikan kadar TSS pada waktu 3 jam. Hasil yang diperoleh ini dikarenakan pada waktu kontak 3 jam selulosa daun mahkota nanas sebagai adsorben sudah mendekati titik jenuh sehingga logam yang sudah diikat dilepas lagi dan dari uji statistik dengan tingkat kepercayaan $95 \%$ diketahui bahwa dengan variasi penambahan selulosa dari hasil rata- rata 3 kali pengulangan terdapat beda nyata dari semua perlakuan, selain itu menurut Peraturan Menteri Lingkungan Hidup Republik Indonesia Nomor 5 Tahun 2014 Tentang Baku Mutu Air Limbah kadar TSS yang diperoleh dalam penelitian ini sudah memenuhi baku mutu air limbah. 
Kemampuan Selulosa Daun Mahkota Nanas

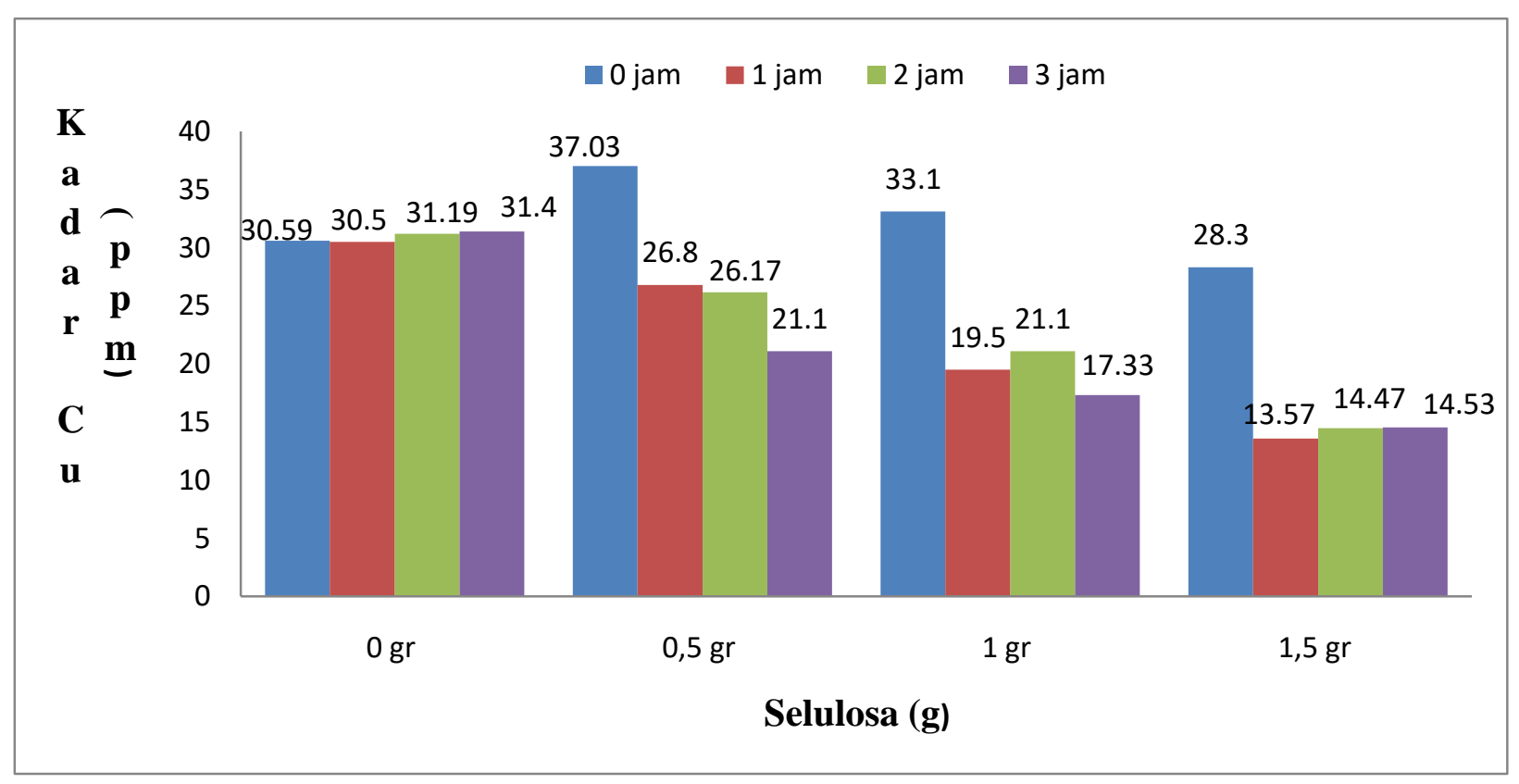

Gambar 2. Kadar logam $\mathrm{Cu}$ dengan variasi penambahan selulosa daun mahkota nanas dan variasi waktu kontak

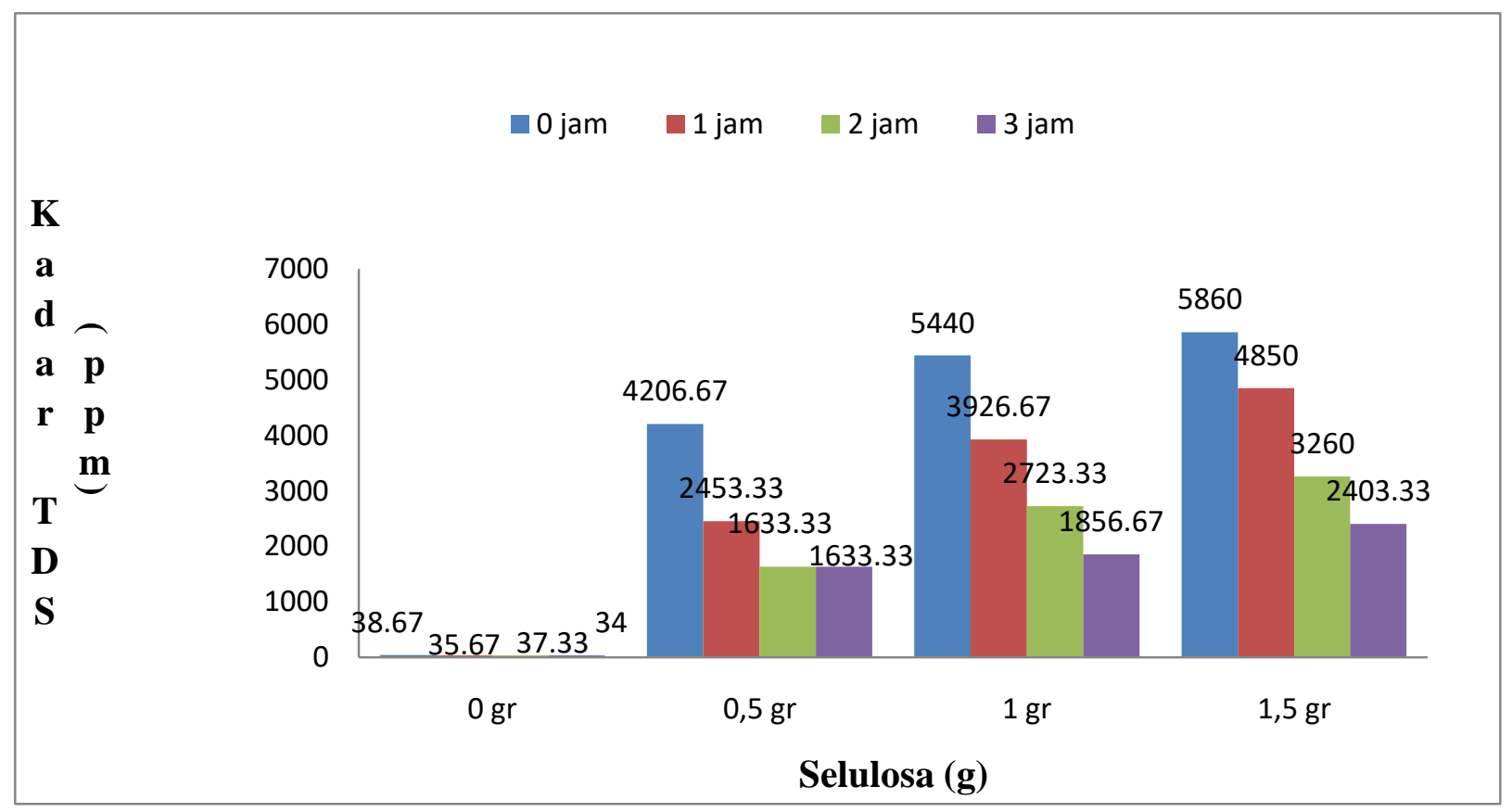

Gambar 3. Kadar TDS logam $\mathrm{Cu}$ dengan variasi penambahan selulosa daun mahkota nanas dan variasi waktu kontak 


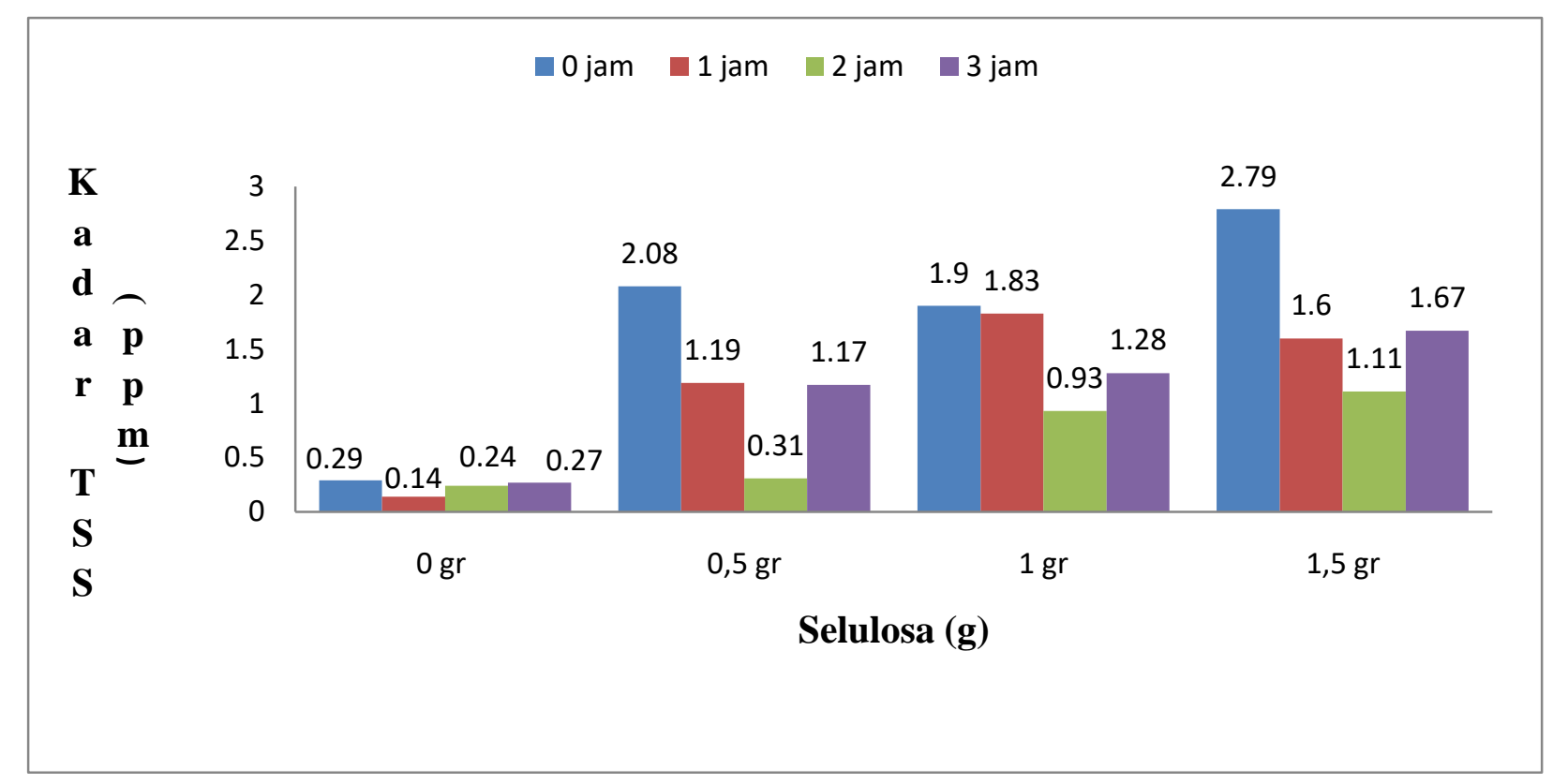

Gambar 4. Kadar TSS logam Cu dengan variasi penambahan selulosa daun mahkota nanas dan variasi waktu kontak

\section{Pengukuran pH}

Nilai $\mathrm{pH}$ yang dihasilkan dalam penelitian ini dapat dilihat pada Gambar 5.

Berdasarkan Gambar 5 dapat diketahui jelas bahwa kondisi asam terdapat pada perlakuan tanpa penambahan selulosa karena logam berat $\mathrm{Cu}$ yang mengandung senyawa $\mathrm{CuCl}_{2}$ bersifat asam di dalam air. Sedangkan pada perlakuan dengan penambahan selulosa $\mathrm{pH}$ yang dihasilkan cenderung bersifat basa (tinggi) yakni 9,42- 12,58. Hasil yang diperoleh sesuai dengan hasil penelitian Chunfeng (2009), yang menyatakan bahwa secara umum besarnya logam yang teradsorb akan naik pada $\mathrm{pH}$ lebih besar dari 6. Pada $\mathrm{pH}$ yang rendah dan bersifat asam akan menyebabkan konsentrasi ion $\mathrm{H}^{+}$ akan naik dan akan terjadi kompetisi antara ion $\mathrm{H}^{+}$dan ion logam untuk bertukar tempat dengan kation lain pada adsorben. Berdasarkan uji statistik dengan tingkat kepercayaan 95\% terdapat beda nyata dari semua perlakuan dan menurut Peraturan Menteri Lingkungan Hidup Republik Indonesia Nomor 5 Tahun 2014 Tentang Baku Mutu Air Limbah nilai pH yang diperoleh pada penelitian ini belum memenuhi baku mutu air limbah.

\section{Korelasi dan Regresi Kadar Logam Tembaga (Cu) dengan variasi penambahan selulosa dan waktu}

Berdasarkan hasil analisis korelasi dan regresi menunjukkan bahwa variasi penambahan selulosa daun mahkota nanas dan variasi waktu memiliki hubungan dengan kadar logam tembaga sebesar 0,838 atau $83,8 \%$. Pengaruh variabel bebas (waktu dan selulosa) terhadap variabel terikat (kadar $\mathrm{Cu}$ ) dapat dilihat pada Gambar 6. 


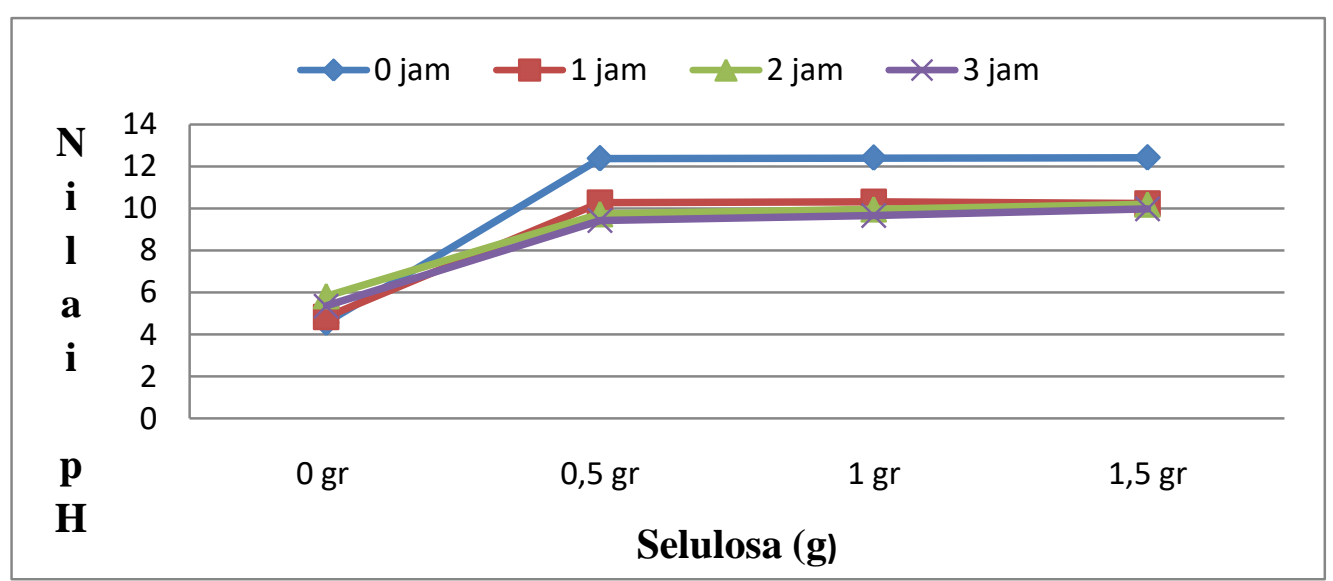

Gambar 5. Nilai $\mathrm{pH}$ limbah $\mathrm{Cu}$ dengan variasi penambahan selulosa daun mahkota nanas dan variasi waktu kontak

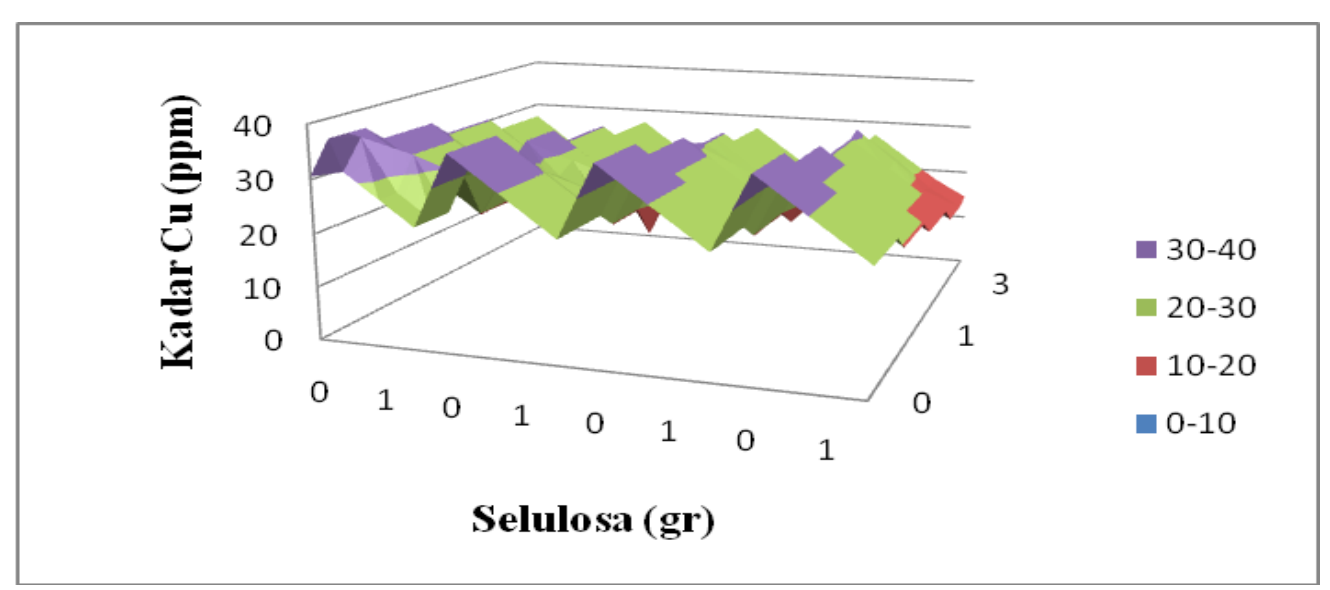

Gambar 6. Pengaruh variasi penambahan selulosa daun mahkota nanas dan variasi waktu kontak terhadap kadar $\mathrm{Cu}$

Hasil perhitungan regresi dalam penelitian dengan menggunakan SPSS didapatkan persamaan di bawah ini:

$$
\begin{aligned}
& \mathrm{Y}=43,627-3,126 \mathrm{X}_{1}-4,385 \mathrm{X}_{2} \\
& \text { Keterangan: } \\
& \mathrm{Y}=\mathrm{Cu} \\
& \mathrm{X}_{1}=\text { waktu } \\
& \mathrm{X}_{2}=\text { selulosa }
\end{aligned}
$$

\section{Korelasi dan Regresi Kadar TDS dengan variasi penambahan selulosa dan waktu}

Berdasarkan hasil analisis korelasi dan regresi menunjukkan bahwa variasi penambahan selulosa daun mahkota nanas dan variasi waktu memiliki hubungan dengan kadar TDS sebesar 0,909 atau $90,9 \%$. Pengaruh variabel bebas (waktu dan selulosa) terhadap variabel terikat (TDS) dapat dilihat pada Gambar 7.
Hasil perhitungan regresi dalam penelitian dengan menggunakan SPSS didapatkan persamaan di bawah ini.

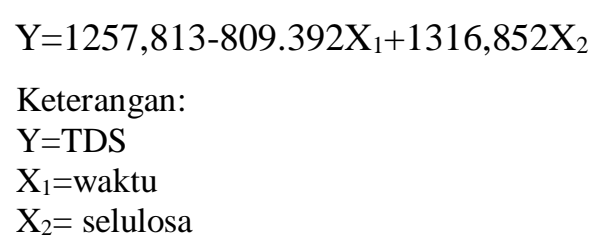

\section{Korelasi dan Regresi Kadar TSS dengan variasi penambahan selulosa dan waktu}

Berdasarkan hasil analisis korelasi dan regresi menunjukkan bahwa variasi penambahan selulosa daun mahkota nanas dan variasi waktu memiliki hubungan dengan kadar TSS sebesar 0,755 atau $75,5 \%$. Pengaruh variabel bebas (waktu dan selulosa) terhadap variabel terikat (TSS) dapat dilihat pada Gambar 8. 


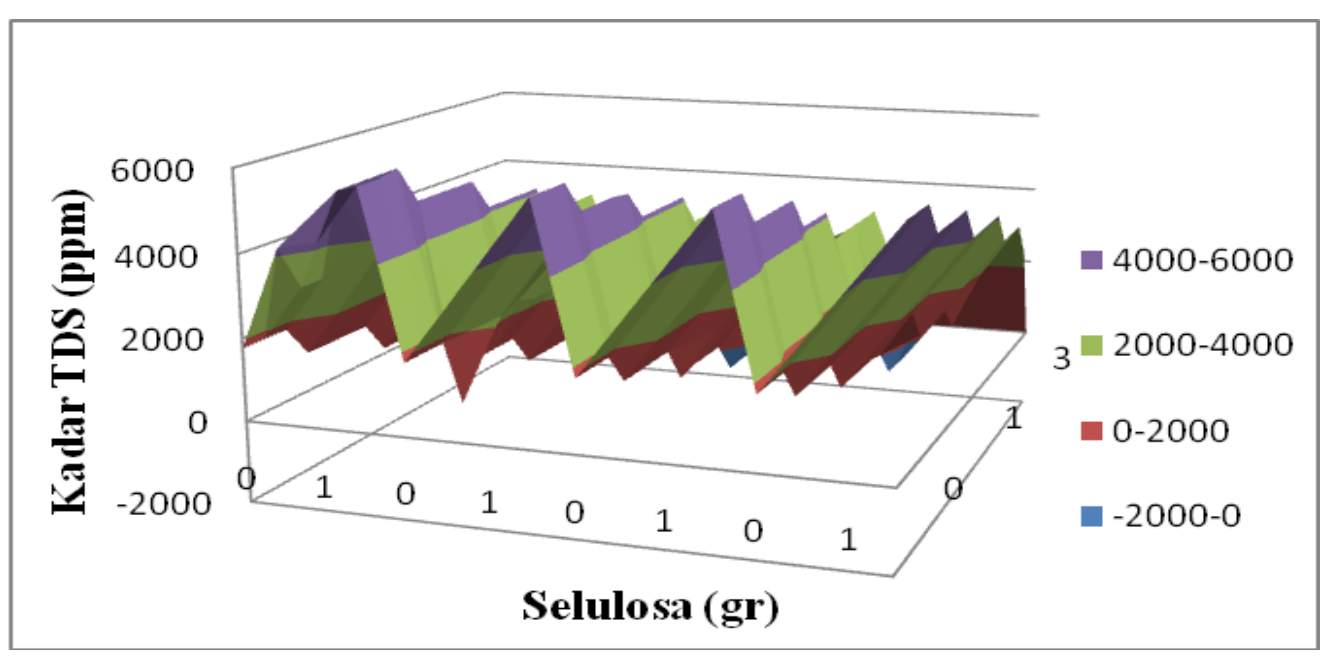

Gambar 7. Pengaruh variasi penambahan selulosa daun mahkota nanas dan variasi waktu kontak terhadap kadar TDS

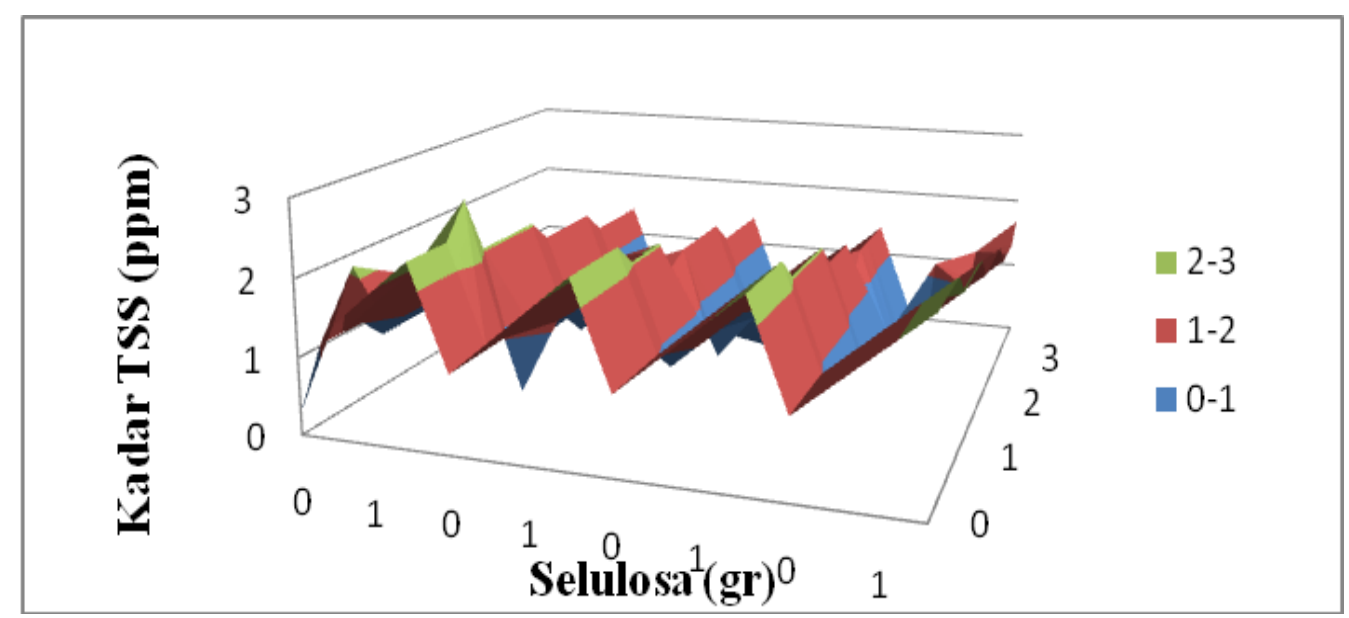

Gambar 8. Pengaruh variasi penambahan selulosa daun mahkota nanas dan variasi waktu kontak terhadap kadar TSS

Hasil perhitungan regresi dalam penelitian dengan menggunakan SPSS didapatkan persamaan di bawah ini.

$$
\begin{aligned}
& Y=0,579-0,2 \\
& \text { Keterangan : } \\
& Y=\text { TSS } \\
& X_{1}=\text { waktu } \\
& X_{2}=\text { selulosa }
\end{aligned}
$$

\section{Korelasi dan Regresi Nilai pH dengan variasi penambahan selulosa dan waktu}

Berdasarkan hasil analisis korelasi dan regresi menunjukkan bahwa variasi penambahan selulosa daun mahkota nanas dan variasi waktu memiliki hubungan dengan nilai $\mathrm{pH}$ sebesar 0,777 atau $77,7 \%$. Pengaruh variabel bebas (waktu dan selulosa) terhadap variabel terikat (pH) dapat dilihat pada Gambar 9.

Hasil perhitungan regresi dalam penelitian menggunakan SPSS didapatkan persamaan di bawah ini.

$\mathrm{Y}=6,411-0,554 \mathrm{X}_{1}-1,679 \mathrm{X}_{2}$

Keterangan:

$\mathrm{Y}=\mathrm{pH}$

$\mathrm{X}_{1}=$ waktu

$\mathrm{X}_{2}=$ selulosa 


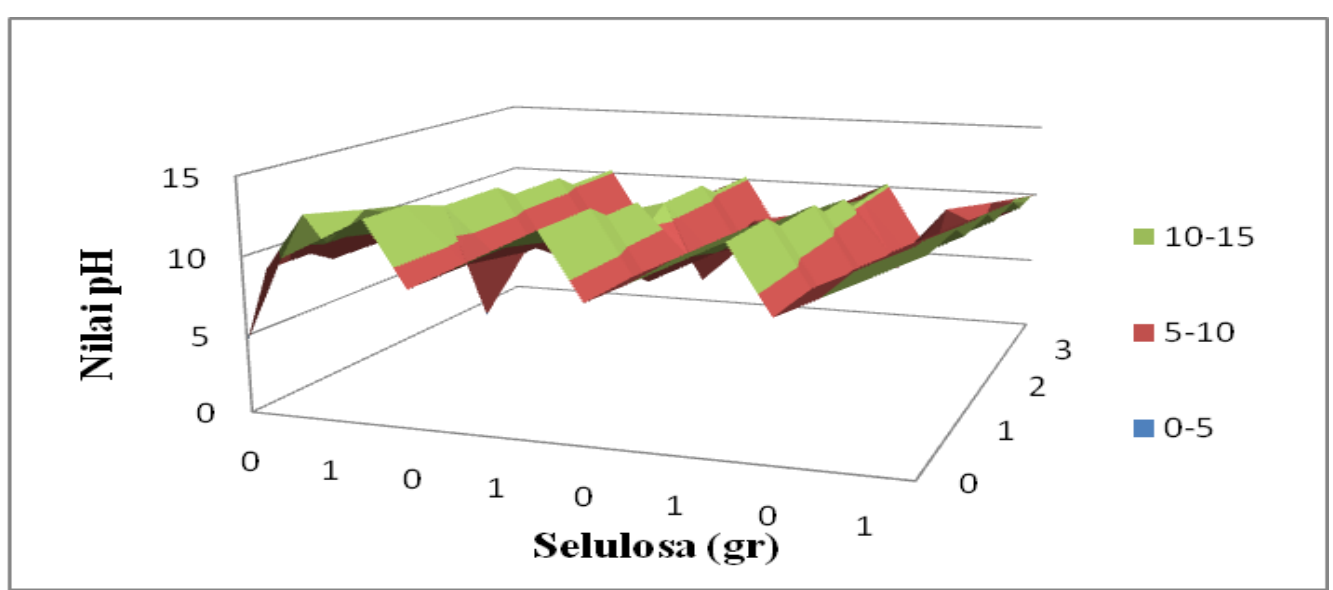

Gambar 9. Pengaruh variasi penambahan selulosa daun mahkota nanas dan variasi waktu kontak terhadap nilai $\mathrm{pH}$

\section{Simpulan dan Saran}

\section{Simpulan}

Selulosa daun mahkota nanas (Ananascomosus) mampu mengadsorbsi logam tembaga $(\mathrm{Cu})$ sebesar $72,86 \%$. Selulosa daun mahkota nanas mampu mengadsorbsi logam tembaga $(\mathrm{Cu})$ secara optimal sebesar 1, 5 gram dan dalam waktu 1 jam. Pengaruh penambahan selulosa dan variasi waktu memberikan pengaruh, yakni penurunan kadar $\mathrm{Cu}$, kenaikan kadar TDS, kadar TSS dan nilai $\mathrm{pH}$.

\section{Saran}

Variasi selulosa daun mahkota nanas dengan variasi kontak untuk mengadsorbsi logam berat tembaga $(\mathrm{Cu})$ ditambah. Mencari sumber selulosa dari bahan alami lain. Logam berat lain menggunakan selulosa daun mahkota nanas seperti $\mathrm{Zn}, \mathrm{Pb}, \mathrm{Ag}$, Cd dan lain - lain.

\section{Daftar Pustaka}

Adinugraha, M.P., Marseno, D.W. dan Haryadi. 2005. Synthesis and Characterization of Sodium Carboxymethyl Cellulose from Cavendish Banana Pseudo Stem (Musa Cavendishii Lambert). Carbohydrate Polymers, 62: 164169.

Chunfeng, W. 2009. Evaluation Of Zeolites Synthesized From Fly Ash Potential Adsorbents For Wastewater Containing Heavy Metals. Journal of environmental sciences, Volume 21 (1): 127136.
Effendi, H. 2003. Telaah Kualitas Air Bagi Pengelolaan Sumber Daya dan Lingkungan. Kanisius. Yogyakarta.

Handayani, A.W. 2010. Penggunaan Selulosa Daun Nanas Sebagai Adsorben Logam Berat Cd (II). Skripsi. Fakultas Matematika Dan Ilmu Pengetahuan Alam Universitas Sebelas Maret, Surakarta.

Hidayat, P. 2008. Teknologi Pemanfataan Serat Daun Nanas sebagai Alternatif Bahan Baku Tekstil, Teknoin, 13 (5): 31-35.

Kirby. 1963. Vegetable Fibres. Leonard Hill, London.

Lestari, S., Sugiharto, E. dan Mudasir. 2003. Studi Kemampuan Adsorpsi Biomassa Saccharomyces cerevisiae yang Terimobilkan Pada Silika GeI terhadap Tembaga (II). Teknosains, 16A (3): 357371.

Norman, A.G. 1937. The Composition of Same Less Common Vegetable Proses. Biochemistry Section, 1575-1578.

Peraturan Menteri Lingkungan Hidup Republik Indonesia Nomor 5 Tahun 2014 Tentang Baku Mutu Air Limbah.

Safrianti, I., Wahyuni, N. dan Zaharah, T.A. 2012. Adsorpsi Timbal (II) oleh Selulosa Limbah Jerami Padi Teraktivasi Asam Nitrat pengaruh $\mathrm{pH}$ dan Waktu Kontak. $J K K, 1$ (1): $1-7$.

Sumardjo, D. 2009. Pengantar Kimia. Penerbit Buku Kedokteran EGC, Jakarta

Widowati dan Wahyu. 2008. Efek Toksik Logam. ANDI, Yogyakarta. 